\title{
O SURGIMENTO DA CORTE PERMANENTE DE JUSTIÇA INTERNACIONAL: FORMAÇÃO EUROPEIA E FUNDAMENTO VOLUNTARISTA
}

\section{THE RISE OF THE PERMANENTE COURT OF INTERNATIONAL JUSTICE: EUROPEAN FORMATION AND THE VOLUNTARIST SUPPORT}

\begin{abstract}
LUCAS CARLOS LIMA
Mestrando em Direito Internacional pelo Programa de Pós-Gradução em Direito da Universidade Federal de Santa Catarina. Pesquisador do lus Gentium - Grupo de Pesquisa em Direito Internacional UFSC/CNPq, possui sua linha de pesquisa voltada para tribunais internacionais e arbitragem internacional.
\end{abstract}

\section{RESUMO}

A Corte Permanente de Justiça Internacional (19211940) nasce ante um debate que conjeturava uma jurisdição internacional permanente e de que maneira ela se relacionava com o modelo arbitral anterior. 0 objetivo do presente trabalho é conhecer esse debate para que, em seguida, seja realizada breve análise da estrutura jurídica que se soergueu na Corte Permanente de Justiça Internacional, no seio da Liga das Nações. Muito embora não se possa abordar toda a complexidade dos institutos e dos dispositivos que regulam a Corte (em essência, seu Estatuto, seu regulamento e as ordonnances pela Corte emitida), buscar-se-á dar destaque aos principais dispositivos que firmam uma ideia de permanência naquela Corte, bem como aqueles que estejam mais aproximados da composição arbitral.

Palavras-chave: Arbitragem Internacional; Corte Permanente de Justiça Internacional; História do Direito Internacional;

\begin{abstract}
The Permanent Court of International Justice (19211940) was risen before debates which conjectured a permanent international jurisdiction and in which way it was related to the previous arbitral model. The intent of the present work is to understand this debate so that thereafter a brief analysis of the juridical structure that arose in the Permanent Court of International Justice, within the pale of the League of Nations, is made. Due to the fact that the entire complexity of the institutes and dispositives which regulate this Court (essencially its Statute, its regulations and its ordonnances) cannot be fully studied, it will be given eminence to the main dispositives which firm an idea of permanence in such Court, as well as those which are closer to the arbitral composition.
\end{abstract}

Keywords: International Arbitration; International Legal History; Permanent Court of International Justice.

\section{SUMÁRIO}

INTRODUÇAO; 1 DEBATES PRELIMINARES PARA O NASCIMENTO DE UMA CORTE PERMANENTE; 2 AS RAÍZES VOLUNTARISTAS DA PRIMEIRA JURISDIÇÃO INTERNACIONAL; CONCLUSÃO; REFERÊNCIAS. 
O SURGIMENTO DA CORTE PERMANENTE DE JUSTIÇA INTERNACIONAL: FORMAÇÃO EUROPEIA E FUNDAMENTO VOLUNTARISTA

\section{INTRODUÇÃO}

A ciência do direito internacional observa o fenômeno da Liga das Nações ${ }^{1}$ com os olhos atentos de quem vê delinear-se diante de si o erigir de um novo modelo de sociedade internacional. Se os velhos acordos europeus (agora tendo como partes também o Estados Unidos e Japão) estão transfigurados numa nova fórmula, isto não importa aos olhos dos juristas que necessitam trabalhar, teorizar, responder às demandas da primeira organização internacional que se pretendia universal. No Pacto da Liga de 1919, um artigo chama especial atenção daqueles que acompanhavam o fenômeno:

O Conselho é incumbido de preparar um projeto de Corte permanente de Justiça internacional e de submetê-lo aos membros da Sociedade. Essa Corte conhecerá de todas as controvérsias de caráter internacional que as partes the submetam. Também dará pareceres consultivos sobre toda controvérsia ou questão a ela submetida pelo Conselho ou a Assembleia.

Pelo artigo 14, uma corte internacional permanente seria criada2. Contudo, distanciando-se da maneira como parte dos estudiosos aborda sua criação, o trabalho da Liga não é um trabalho completamente novo e genuíno, não cria uma instituição do alto das mentes iluminadas dos comissários da Liga. A ideia de uma corte permanente é um longo itinerário histórico, repleto de continuidades e descontinuidades, cujo gérmen se desenvolvia desde o final do século XIX3.

\footnotetext{
1 A Liga ou Sociedade das Nações (1919-1946), foi a primeira organização internacional de vocação universal de caráter permanente. Tendo como objetivos a segurança internacional coletiva e a igualdade entre os Estados soberanos, a Liga foi uma organização do entreguerras que fracassou em seu objetivo de salvaguardar a paz por uma série de razões. Contudo, serviu de suporte basilar para a existência da primeira jurisdição internacional permanente. Para maiores informações, ver VELAZCO, Manuel Diez de. Las Organizaciones Internacionales. Madrid: Tecnos, 2006.

${ }^{2}$ A diferenciação entre a nomenclatura Corte e Tribunal diverge tanto conceitualmente quanto em relação ao sistema jurídico que a está adotando. Em teoria, um Tribunal seria um órgão mais específico, voltado a determinada matéria ou a determinado fim, enquanto uma Corte teria um caráter mais universal voltado à maior abertura e sem delimitação de matéria. Ainda que no Brasil a nomenclatura Corte seja preterida no âmbito do poder judiciário, e ainda que a nomenclatura Tribunal Internacional de Justiça seja utilizada por outros países de língua portuguesa, como Portugal, utilizar-se-á a nomenclatura "Corte Permanente de Justiça Internacional", respeitando as versões francesa e inglesa do Estatuto, bem como optando pela diferenciação doutrinal. Além disso, nos documentos diplomáticos de aceitação da Corte ( 0 procotolo) a versão do Brasil é "Corte Permanente de Justiça Internacional", bem como "Corte Internacional de Justiça".

${ }^{3}$ Sobre o assunto, ver LIMA, L. C. ; DAL RI JUNIOR, A . O desenvolvimento da arbitragem internacional ao longo do século XIX como movimento precursor das convenções da paz de haia de 1899 e 1907. In: $9^{\circ}$ Congresso Brasileiro de Direito Internacional, 2011, Brasília. Anais do $9^{\circ}$ Congresso Brasileiro de Direito Internacional, 2011. v. 1. p. 734-742.
} 
O SURGIMENTO DA CORTE PERMANENTE DE JUSTIÇA INTERNACIONAL: FORMAÇÃO EUROPEIA E FUNDAMENTO VOLUNTARISTA

LUCAS CARLOS LIMA

Da tentativa infrutífera de tribunal permanente que foi a Corte Permanente de Arbitragem4, de 1907 a 1919, doze anos se passaram e o debate permanecia vivo no seio da ciência jurídica. Muito embora parte da comunidade internacional estivesse envolvida na guerra, o que imobilizou parcialmente a Europa, os estudiosos de direito internacional não deixaram de alimentar a discussão acerca da jurisdição internacional: seja identificando as deficiências ou características negativas da arbitragem, seja propagandeando a ideia de uma jurisdição internacional permanente.

Ante esse contexto, o objetivo do presente trabalho é o de analisar o surgimento do primeiro órgão de jurisdição internacional permanente, realizando a devida contextualização histórica com os debates na ciência jurídica internacional sobre seu surgimento. Conjuntamente à apresentação da Corte, o escopo é o de perceber duas de suas principais características: a formação eminentemente europeia e o cunho voluntarista de sua composição, percebendo, pois, os postulados teóricos que norteiam a atividade jurisdicional da Corte. Buscando tal intento, o artigo examinará fontes bibliográficas do período, verificando como a doutrina internacionalista encara o fenômeno buscando pontos de concordância e ruptura nas vozes doutrinais. Será igualmente analisada as discussões ocorridas no âmbito da Comissão de Juristas nomeada para elaboração do Estatuto da Corte Permanente de Justiça Internacional (doravante Comissão ou Comissão de Juristas), como maneira de identificar a formação europeia e o fundamento voluntarista de referenciado órgão de solução de controvérsias.

\section{DEBATES PRELIMINARES PARA O NASCIMENTO DE UMA CORTE PERMANENTE}

A Corte Permanente de Justiça Internacional nasce num momento histórico cujos debates ainda rescendem à arbitragem internacional, suas características e deficiências. 0 debate, portanto, tem como discurso a prática imediatamente anterior vivenciada pela arbitragem internacional. A discussão se perfectibiliza, sobretudo, ante a análise do sistema

\footnotetext{
${ }^{4}$ A Criada pelas Conferências Internacionais da Paz de Haia de 1899 e 1907, a Corte Permanente de Arbitragem (CPA) é um órgão de resolução de conflitos jurídicos entre Estados que ainda hoje se encontra em funcionamento. A Corte representou o primeiro esforço de institucionalização de um tribunal permanente. De 1902 a 1934 foram submetidos 21 casos de arbitragem à CPA, que funcionava mais como um maquinário de composição de tribunais que propriamente como um órgão permanente e à disposição dos Estados.
} 
O SURGIMENTO DA CORTE PERMANENTE DE JUSTIÇA INTERNACIONAL: FORMAÇÃO EUROPEIA E FUNDAMENTO VOLUNTARISTA

LUCAS CARLOS LIMA

arbitral erigido das Convenções de Haia com a Corte Permanente de Arbitragem. O alemão Hans Wehberg $^{5}$ realiza uma ampla crítica do período, afirmando a impossibilidade de realizar um efetivo desenvolvimento do direito internacional com as decisões arbitrais. Segundo o internacionalista, decisões conflitantes abordando direito internacional de maneiras distintas são encontradas quando se analisa o corpo de laudos arbitrais proferidos, chegando até mesmo a configurarem-se contraditórias entre $\mathrm{si}^{6}$. A problemática que emerge desta informação é que, se é possível considerar as decisões arbitrais como uma fonte ${ }^{7}$ do direito internacional, que dizer destas fontes quando se contradizem, quando respondem de maneiras diversas um determinado fato jurídico? Daí a crítica que se assevera a essa tênue construção arbitral do direito internacional no período.

Outro ponto de discussão que se tornava alvo de críticas é o caráter político, de mediação, que por vezes as arbitragens assumiam. Segundo Lassa Oppenheim ${ }^{8}$, um árbitro muitas vezes tem de satisfazer as duas partes, agindo quase como um mediador do que verdadeiramente como um juiz ${ }^{9}$. Os árbitros muitas vezes decidem mais pela equidade que propriamente pelo direito $^{10}$. Segundo o francês Georges Scelle ${ }^{11}$, era necessário um:

[...] verdadeiro organismo, com uma existência material, uma equipe de carne e osso, suscetível de adquirir uma autoridade considerável sobre a opinião universal, concebido inclusive, por certos espíritos, como uma espécie de

\footnotetext{
${ }^{5}$ Hans Wehberg (1885-1862), nascido em Duesseldorf, Alemanha, é um dos grandes professores de direito internacional deste país, ganhando também destaque como um dos fundadores da doutrina pacifista do direito internacional. Como pacifista, estudou e acompanhou o movimento da criação da Liga das Nações e das Cortes Internacionais em oposição à arbitragem com especial atenção. Sua obra "The Problem of an International Court of Justice", de 1918 mas originalmente publicada em 1912 reflete bastante bem o debate anterior à criação da Corte.

${ }^{6}$ WEHBERG, 1918, p.342.

${ }^{7}$ A título de exemplo, T. J. Lawrence, membro do Institut de Droit International, professor de Direito Internacional em diversas Universidades anglo-saxãs, considera as decisões dos tribunais internacionais de arbitragem como fonte do direito internacional. Ainda que só crie decisões entre as partes determinadas decisões arbitrais podem "abraçar" todos os sujeitos que se vejam relacionados. (LAWRENCE, 1920, p.113)

${ }^{8}$ Lassa Francis Lawrence Oppenheim (1858-1919), internacionalista alemão com cidadania britânica, foi professor de direito internacional na Universidade de Cambridge, sendo um dos principais nomes do direito internacional do início do século XX, sobretudo por sua obra "International Law: A Treatise ${ }^{9}$ OPPENHEIM, 1921, p.47.

${ }^{10}$ Neste sentido Wehberg: "When we realize in addition that international arbitration by its very nature calls for a decision according to equity, we see immediately that it is a mistake to introduce into arbitration the judicial element of a strictly legal decision". (WEHBERG, 1918, p.39)

${ }^{11}$ Georges Scelle (1878-1961), foi um internacionalista francês da primeira metade do século XX. Professor de Direito Internacional Público na Faculdade de Dijon por 20 anos, foi também membro da Comissão de Direito Internacional da ONU, bem como membro do Institut de Droit Internacional e da Corte Permanente de Arbitragem desde 1950. Scelle é um dos importantes nomes da Escola Francesa do Direito Internacional, que reúne concepções antiformalistas e não-Estatalistas do fenômeno jurídico internacional.
} 
O SURGIMENTO DA CORTE PERMANENTE DE JUSTIÇA INTERNACIONAL: FORMAÇÃO EUROPEIA E FUNDAMENTO VOLUNTARISTA

LUCAS CARLOS LIMA

personalidade internacional independente dos Estados, e moralmente superior a eles, vez que ela haverá a tarefa de julgá-los ${ }^{12}$.

É na crítica a esse modelo que o debate se reacende e propostas de uma corte permanente tomam corpo no discurso internacionalista. Além disso, o século XX iniciava um lento processo de codificação do direito internacional no número de tratados que vinham firmados, na esteira das Convenções de Haia. A Liga das Nações igualmente corroborava esse movimento de codificação de maneira que se faria necessário um órgão internacional para resolver as disputas oriundas desse novo e rico instrumental ${ }^{13}$.

Intuindo esse ebulir da Comunidade Internacional e motivados pela experiência do início do século, diversos países realizam propostas de Corte e trocam correspondência entre si. Dinamarca, Países Baixos, Noruega, Suíça e Suécia oferecem uma notável contribuição neste sentido $^{14}$. Nos Estados Unidos, em 1910, é criada a American Society for the Judicial Settlement of International Disputes ${ }^{15}$, presidida por James Brown Scott ${ }^{16}$, voltada a discutir a corte permanente.

E James Brown Scott revela que em 1918 havia uma cooperação entre França e Inglaterra para a instituição de um tribunal. As iniciativas deslocam-se, pois, em duas vias ${ }^{17}$. Uma delas institucional, entre os Governos, e a outra no âmbito acadêmico, no qual a discussão floresce $^{18}$.

\footnotetext{
${ }^{12}$ SCELLE, 1919, p.71. Do original: "un véritable organisme, ayant une existence matérielle, un personnel en chair et en os, susceptible d'acquérir une autorité considérable sur l'opinion universelle, conçue même, par certains esprits, comme une sorte de personnalité internationale indépendante des Etats, et moralement leur supérieure, puisqu'elle aurait pour tâche de les juger"

${ }^{13}$ CALOYANNI, 1931, p. 776.

${ }^{14}$ HUDSON, 1922, p.250

${ }^{15}$ A American Society for the Judicial Settlement of International Disputes, nascida em Baltimore, 1910, é uma organização cujo objetivo não se concretiza tão somente na criação de um tribunal permanente para resolução de controvérsias internacionais, mas também par a criação de um "sentimento público" que leve os Estados a desenvolverem esta cultura de litígio judicial. Através de suas atividades promoveram-se uma série de debates sobre um tribunal internacional permanente logo após as Convenções de Haia de 1907.

16 James Brown Scott (1866-1943) - Professor das Universidades de Illinois, Columbia e na George Washington University, foi especialista técnico da delegação americana na Segunda Conferência da Paz de Haia (1907). Brown Scott é um dos principais nomes que estudaram o nascimento das jurisdições internacionais, desde as conferências da Paz de Haia até a Corte Permanente de Justiça Internacional.

${ }^{17}$ SCOTT, 1918, p.11.

${ }^{18}$ Hans Wehberg conta que na Inglaterra juristas como Oppenheim, Lawrence, Higgins, Whittuck, Darby, Barclay colocam-se na lista dos que advogam uma Corte, trabalhando-a em suas obras. Em sua própria Alemanha, Wehberg cientifica que Heinrich Lammasch e Franz Von Liszt defendem uma Corte Permanente, em oposição às críticas de Otfried Nippold e Heinrich Pohl ${ }^{18}$, a título de exemplo. (WEHBERG, 1918, p. 241).
} 
O SURGIMENTO DA CORTE PERMANENTE DE JUSTIÇA INTERNACIONAL: FORMAÇÃO EUROPEIA E FUNDAMENTO VOLUNTARISTA

LUCAS CARLOS LIMA

É nesse panorama de discussão, debate, defesa e ataque a uma corte permanente, que a Liga das Nações vai estabelecer o aludido artigo 14. Sendo uma obrigação do Conselho da Liga preparar o projeto, este órgão nomeia uma comissão de dez renomados juristas para conduzir os trabalhos. Munidos de diversos documentos, projetos e esboços de uma Corte internacional, o corpo de juristas possui amplo material de trabalho sobre o qual se debruçar a fim de responder ao conselho quais seriam os contornos da nova instituição.

Com nomenclaturas diversas ${ }^{19}$ (Corte internacional, conforme o projeto do Coronel House $^{20}$; Tribunal Internacional, no projeto francês; Corte internacional de justiça, no projeto italiano, Corte arbitral, no projeto de Lord Robert Cecil; Corte permanente de justiça internacional, no projeto britânico de 1919, denominação escolhida posteriormente), os projetos somam-se à experiência jurídica de cada um dos membros do Comitê que eram - via de regra figuras envolvidas no debate acerca da jurisdição internacional.

Sob a presidência do Barão Descamps ${ }^{21}$, secretariada por Dionísio Anzilotti e tendo como relator Albert de Lapradelle ${ }^{22}$, a Comissão de Juristas nomeada para preparar o Estatuto da Corte Permanente de Justiça Internacional realiza seus trabalhos de 16 de junho a 24 de julho de 1920. Composta por Adatci, (Japão); Altamira (Espanha); Descamps (Belga); Fernandes ${ }^{23}$, (Brasil); Hagerup, (Noruega); de Lapradelle, (França); Loder, (Países Baixos); Phillimore, (Grã-

\footnotetext{
${ }^{19}$ ROUSSEAU, 1983, p.400.

${ }^{20}$ Edward Mandell House (1858-1938), é um diplomata americano muito próximo de Woodrow Wilson, sendo conselheiro de política externa do mesmo. É uma figura bastante controversa acerca da Liga das Nações diante da influência que exercia para os acordos do pacto. Segundo Edward Carr: "Nos assuntos da Liga das Nações, a igualdade formal e a participação de todos no debate não tornaram o fator poder nem um pouco menos decisivo. Os próprios fundadores da Liga não alimentavam tal ilusão. House pensava, originariamente, que só as grandes potências deveriam ser admitidas na Liga" (CARR, 2001, p.137)

${ }^{21}$ Barão Édouard Eugène Descamps (1847-1933), é um político belga formado pela Université de Louvain, instituição na qual também lecionou. Foi representante da Bélgica na $1^{\mathrm{a}}$ e $2^{\mathrm{a}}$ Conferência de Haia, sendo um militante da solução pacífica de conflitos internacionais. Nestas ocasiões, Descamps destacou-se pessoalmente por seus debates com Rui Barbosa defendendo as Grandes Potências.

${ }^{22}$ A escolha de Lapradelle igualmente não surpreende. Além de possuir uma ampla obra em relação à temática, juntamente com Politis ele organizou os Recueil dês arbitrages internationaux, de maneira que possuía amplo conhecimento da dinâmica arbitral entre os Estados. Ademais, Lapradelle também possuía um projeto de Corte pessoal em nome da União Interparlamentar antes referenciada. Cf. Documents presented to the committee relating to existing plans for the establishment of a Permanent Court of International Justice, 1920.

${ }^{23}$ Raul Fernandes (1877-1967), político e diplomata brasileiro, foi Ministro das Relações Exteriores do Brasil nos Governos Dutra e Café Filho. Após o término da Primeira Guerra Mundial, foi nomeado Delegado Plenipotenciário à Conferência de Paz de Paris (1919) e representante do Brasil na Comissão de Reparações, de 1919 a 1920. Fonte: Wikipedi - http://pt.wikipedia.org/wiki/Raul_Fernandes Acessado em: $21 / 11 / 2011$.
} 
O SURGIMENTO DA CORTE PERMANENTE DE JUSTIÇA INTERNACIONAL: FORMAÇÃO EUROPEIA E FUNDAMENTO VOLUNTARISTA

LUCAS CARLOS LIMA

Bretanha); Ricci-Busatti, (Itália); Root, (Estados Unidos), tinha como assessor jurídico James Brown Scott (EUA).

Eminentemente composta por juristas Europeus (eram 7 dos 10), a Comissão elaborou um avant-projet emitido ao Conselho da Liga das Nações que após algumas modificações tuteladas por Leon Bourgeois ${ }^{24}$ foi submetido à aprovação da Assembleia da Liga ${ }^{25}$.

Um dos principais problemas sobre os quais a comissão se debruçou era exatamente o mesmo que havia emperrado os trabalhos da pretensa Corte de Justiça Arbitral nas Convenções de Haia de 1907: a escolha dos juízes. Diretamente influenciados pela ideia da Suprema Corte Americana $^{26}$ (que representa os 30 Estados confederados), os membros da comissão entenderam que a Corte deveria possuir número de 15 juízes. Como ocupar tais cadeiras? Para os representantes das grandes potências como o japonês Adatci e o inglês Phillipmore as grandes potências deveriam prevalecer na escolha, enquanto o brasileiro Raúl Fernandes e o norueguês Hagerup acreditavam na força dos estados médios ${ }^{27}$.

A solução encontrada pelo americano Elihu Root ${ }^{28}$ foi a própria natureza da Liga quem ofereceu (motivo pelo qual mais uma vez se reforça a ideia da importância de uma jurisdição internacional nascer no âmago de uma Organização Internacional). Assim como na aprovação do

\footnotetext{
${ }^{24}$ Léon Victor Auguste Bourgeois (1851-1925), político e diplomata francês, foi laureado com o prêmio Nobel da paz em 1920 e é igualmente reconhecido como teórico do solidarismo. Foi o primeiro presidente da Liga das Nações, em 1920, membro da Corte Permanente de Arbitragem de Haia e Ministro das Relações Exteriores francês. Bourgeois é um dos nomes chave da formação da Liga e, igualmente, da CPJI. ${ }^{25}$ Muito embora o debate guarnecido no corpo da Comissão seja de profunda importância para a compreensão da formação de uma jurisdição internacional, em virtude das delimitações do trabalho não se realizará uma análise profunda dos debates em si, mas sim pontos importantes relativos a ele em cada um dos tópicos da Corte abordado. Os debates se encontram disponíveis em: Procès-verbaux of the Advisory Committee of Jurists on the Statute of the Permanent Court of International Justice, 1920. Disponível em: http://www.icj-cij.org/pcij/other-documents.php?p1=9\&p2=8. Acesso em: 11 de novembro de 2011.

${ }^{26}$ A influência americana na concepção da Corte é antiga e pode-se verificar na literatura americana diversos defensores desta ideia. A título de exemplo, Robert Goldsmith, na obra A League to enforce peace de 1917 um ama ampla argumentação de como a Corte Suprema dos Estados Unidos funciona como uma Corte de direito internacional entre os Estados da União. 0 debate, em verdade, já era presente nas discussões acerca da Corte de Justiça Arbitral de 1907, como conta James Brown Scott em The Hague Peace Conferences of 1899 and 1907. Vol 1. Baltimore: The Johns Hopkins Press, 1909. Nesse sentido: "It is but natural that the Supreme Court should be the prototype of the permanent tribunal which Mr. Root has in mind, because it was created by the original thirteen States, and in the one hundred and twenty years of its existence it has decided many controversies of an international character between the States of the Union". (SCOTT, 1912, p.317)

${ }^{27}$ ROUSSEAU, 1983, p.401.

${ }^{28}$ Comitê de Juristas, Procès-Verbaux, p.108-9.
} 


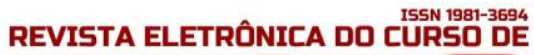

O SURGIMENTO DA CORTE PERMANENTE DE JUSTIÇA INTERNACIONAL: FORMAÇÃO EUROPEIA E FUNDAMENTO VOLUNTARISTA

LUCAS CARLOS LIMA

Estatuto seriam o Conselho e a Assembleia trabalhando conjuntamente, a escolha dos juízes seria feita da mesma forma ${ }^{29}$.

Em artigo no American Journal of International Law de 1921, $\operatorname{Root}^{30}$ defende que a questão da escolha dos juízes encontra solução na medida em que os dois sistemas de eleições encontram-se justos. 0 primeiro deles, através da Assembleia, consagra os direitos soberanos de cada um dos estados em encontrar voz no cenário internacional. Em seguida, a das potências, justifica-se igualmente pelo fato de que alguns países possuem uma produção maior, maiores trocas, realizam mais comércio, enfim, possuem preocupações maiores com o destino da justiça internacional, e por isso justifica-se a escolha dos juízes também por parte do Conselho.

O discurso de Root para legitimar o Conselho muito embora venha ornado de tons róseos para convencimento da opinião pública e acadêmica não deixa de revelar o real fator que será sopesado na escolha dos juízes. Não se poderia relegar somente à força democrática representada pela Assembleia a nominação daqueles que iriam (compulsoriamente) decidir a interpretação do Direito Internacional. Sob uma ótica realista, era necessário de alguma forma balizar os limites e os poderes dessa Corte através da indicação acertada dos juízes. Nesse sentido coaduna-se a lição de Charles Rousseau ${ }^{31}$ uma vez que "as duas engrenagens da LDN facilitaram uma solução aceitável para a forma de nomeação, pois a dualidade dos órgãos de Genebra permitiu conciliar os interesses das grandes potências e as suscetibilidades das demais"32.

Contudo, não era apenas de dois órgãos que se realizava a eleição da Corte. Restou igualmente decidido que os nomes dos juízes viriam por indicação dos grupos nacionais que compunham a Corte Permanente de Arbitragem de 1899. Assim, o Conselho e a Assembleia lançariam mão dos nomes apontados pelos representantes dos Estados na CPA de Haia, que agiriam como árbitros internacionais para compor o corpo jurisdicional da Corte ${ }^{33}$.

\footnotetext{
${ }^{29}$ A escolha veio insculpida no artigo $8^{\circ}$ do Estatuto da Corte Internacional de Justiça: "L'Assemblee et le Conseil procedent, indèpendamment l'une de l'autre, a l'election, d'abord des juges titulaires, ensuite des juges suppleants".

${ }^{30}$ ROOT, 1921.

${ }^{31}$ Charles Rousseau (1902-1993) foi um jurista francês especializado na solução de conflitos internacionais, tendo recebido um prêmio da Liga das Nações por uma tese neste sentido. Foi professor na Faculdade de Direito de Paris, bem como diretor do instituto de Altos Estudos Internacionais. Além disso, foi membro do Instituto de Direito Internacional e da Sociedade Francesa de Direito Internacional. É um dos nomes mais profícuos em Direito Internacional francês do século XX.

${ }_{32}$ ROUSSEAU, 1966, p 353.

${ }^{33}$ Conforme o art. 4 do Estatuto da CPJI: "Les membres de la Cour sont elus par l'Assemblee et par le Conseil sur une liste de personnes presentees par les groupes nationaux de la Cour d'Arbitrage, conformement aux dispositions suivantes".
} 
O SURGIMENTO DA CORTE PERMANENTE DE JUSTIÇA INTERNACIONAL: FORMAÇÃO EUROPEIA E FUNDAMENTO VOLUNTARISTA

LUCAS CARLOS LIMA

A importância deste terceiro elemento revela mais uma vez a sutil vinculação que a CPJI possui com a noção Estatal. Ficaria a encargo dos Estados a indicação dos possíveis juízes a compor a primeira jurisdição internacional permanente.

A proposta inicial do Comitê circunscrevia uma jurisdição internacional permanente e obrigatória. Tal proposta encontra refração na Assembleia por parte das grandes potências que não desejam vincular-se obrigatoriamente com uma jurisdição internacional. Salienta-se que a concepção vigente é ainda aquela apegada à arbitragem internacional, de maneira que os Estados não consideram seguro a sua própria soberania abrir mão destas prerrogativas. Assim, reinicia-se o debate quanto à forma de jurisdição da liga, meramente opcional ou obrigatória, de maneira que a solução encontrada foi uma composição das duas modalidades.

A Assembleia adota, então, em 13 de dezembro de 1920, por unanimidade, uma resolução que aceita o Estatuto da Corte Permanente de Justiça Internacional. Contudo, a aprovação da Assembleia não significa a adesão dos Estados da Liga ao Estatuto, havendo necessidade de uma posterior ratificação individual de cada membro da Liga interessado em fazer parte da Corte. Este é um ponto importante que deve ser salientado e que distingue igualmente a CPJI da atual Corte Internacional de Justiça (CIJ) da Organizações das Nações Unidas (ONU). A CPJI não é um órgão da Liga das Nações, muito embora seja contemplada no Pacto da Liga ${ }^{34}$, motivo pelo qual se fazia uma necessária entrada na Corte através do Protocolo de Assinatura ${ }^{35}$.

Assim, o anteprojeto foi enviado para ser firmado pelos Estados em 16 de dezembro de 1920. Ficou decidido que quando a maioria dos Estados ratificasse o Estatuto, ele entraria em vigor, o que ocorreu em 1921, quando foi assinado por 34 estados $^{36}$. O Estatuto seria posteriormente reformado em $1929^{37}$.

\footnotetext{
${ }^{34}$ RANGEL, 2007, p.85.

${ }^{35}$ Segundo Ian Brownlie, a nova Corte possui relações muito mais próximas com a ONU que a anterior com a Liga. Os membros da ONU são membros da Corte, e a Corte é um órgão da ONU (Bronwlie1998, p.710).

${ }^{36}$ POLITIS, 1924, p.156.

37 Em virtude da atividade crescente da Corte e das pequenas defasagens que o Estatuto proporcionava, em março de 1929 um Comitê de Juristas liderado pelos relatores Henri Fromageot e Nicolas Politis começa a trabalhar na revisão do Estatuto. Para Rousseau (1983, p. 363) “A revisão do Estatuto foi uma consequência do êxito imprevisto da Corte, devido a frequência de suas sessões e a multiplicidade dos assuntos. Se sentiu, portanto, rapidamente, a necessidade de colocar a CPJI em condições para cumprir com continuidade a missão cada vez mais pesada que a ela incumbia, por meio de uma organização mais racional" (ROUSSEAU, 1983, p.363). Entre os principais pontos da reforma, estão: a) proclamação do caráter permanente da Corte, que daquele ponto em diante estaria sempre em função, exceto pelas férias judiciárias; b) supressão dos juízes suplentes, sendo, a partir de 1929, 15 juiz a composição total da Corte; c) instituição oficial do juiz nacional no estatuto. Para Manley Hudon, as emendas supriram algumas
} 
O SURGIMENTO DA CORTE PERMANENTE DE JUSTIÇA INTERNACIONAL: FORMAÇÃO EUROPEIA E FUNDAMENTO VOLUNTARISTA

LUCAS CARLOS LIMA

É no ano de 1921 que 34 grupos nacionais apresentam 89 candidatos para serem escolhidos pela Assembleia e Conselho ${ }^{38}$. As eleições ocorrem em setembro de 1921 sem maiores problemas, exceto quanto ao nome do $15^{\circ}$ juiz. Nesse caso, enquanto a Assembleia apoiou determinado candidato, o Conselho desejou outro, de maneira que, seguindo as disposições do Estatuto, criou-se uma comissão para a escolha ${ }^{39}$.

A primeira composição da Corte ficou assim arquitetada: Altamira (Espanha), Anzilotti (Itália), Barbosa (Brasil), de Bustamante (Cuba), Finlay (Grã-Bretanha), Huber (Suíça), Loder (Países Baixos), Moore (Estados Unidos), Nyhohm (Dinamarca), Oda (Japão), Weiss (França), sendo os suplentes Beic-hmann (Noruega), Negulesco (Romênia), Wang Chung-Hui (China), Yovanovitch (Sérvio-Croata-Esloveno).

Essa era a composição da primeira jurisdição internacional permanente e a maneira como vem orquestrada demonstra bem a forma como o poder vinha equilibrado também numa jurisdição internacional. Tal qual o comitê de juristas, a grande maioria dos membros da Corte é de origem europeia (10), contra uma minoria americana (3) e asiática (2). Em igual sentido, pode-se notar que todas as grandes potências permanentes do Conselho (FR, UK, JP, IT e os EUA) elegem um juiz de sua nacionalidade. É compreensível que o rótulo que Corte Permanente de Justiça Internacional possua seja a imagem pública de uma corte europeia, europeia Ocidental. Essa imagem pública refletia, quase exatamente, sua atual composição ${ }^{40}$.

Contudo, uma análise do perfil jurídico da primeira composição também demonstra que uma antiga tradição (criticada) da arbitragem internacional vem renovada. Não mais diplomatas e homens da política, os juízes deverão ser essencialmente "homens da ciência" 41 , professores, alguns magistrados de carreira, mas sobretudo homens que se afastem da influência direta estatal. Segundo Oppenheim, diferentemente dos árbitros, os juízes da Corte deveriam ser não diplomatas, não políticos, mas somente homens treinados em Direito no sentido geral, e em

lacunas óbvias e incluíram algumas mudanças desejáveis, contudo não eram e vitais importâncias para a Corte e alguns dos seus resultados poderiam ser, como foram, reparadas sem uma mudança dos instrumentos existentes. (HUDSON, 1931, p. 345).

${ }^{38}$ As eleições são narradas com pormenores em SCOTT, James Brown. The Election of Judges for the Permanent Court of International Justice. The American Journal of International Law, Vol. 15, No. 4, pp. 556-558, Julho de 1921.

${ }^{39}$ Art. 12 Estatuto da Corte: "Si, apres la troisieme seance d'election, il teste encore des sieges a pourvoir, il peut etre a tout moment forme sur la demande, soit de l'Assemblee, soit du Conseil, une Commission mediatrice de six membres, nommes trois par l'Assemblee, trois par le Conseil, en vue de choisir pour chaque siege non pourvu un nom $k$ presenter $h$ 1'adoption separee de l'Assemblee et du Consei".

${ }^{40}$ MCWHINNEY, 1991, p.101

${ }^{41}$ POLITIS, 1924, p. 161. 


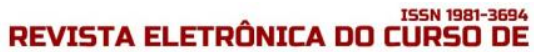

O SURGIMENTO DA CORTE PERMANENTE DE JUSTIÇA INTERNACIONAL: FORMAÇÃO EUROPEIA E FUNDAMENTO VOLUNTARISTA

LUCAS CARLOS LIMA

Direito Internacional no particular. Homens que são linguistas, que dominam o francês mais que a própria língua e que possuam uma "independência de caráter e sejam livres de preconceitos nacionais de toda sorte"42.

Este caráter quase idealizado dos juízes em detrimento ao modelo arbitral em que o “político" e o “diplomata” são vistos nocivamente pela ciência jurídica, faz com que certa aura mistificadora envolva propriamente os juízes. Espera-se deles um comportamento sobrehumano, metafísico, na sua labuta jurisdicional. A título de exemplo, pode-se citar a maneira como Nicolas Politis aborda o primeiro presidente eleito da Corte (para um mandato de 3 $\operatorname{anos}^{43}$ ), Bernard Lorder (1849-1935), afirmando que "em seu soberbo discurso de inauguração, mostrou seu espírito elevado de imparcialidade e independência o dever de conduzir os trabalhos da Corte" 44 .

Tal orientação vinha a consubstanciar o enunciado do artigo $2^{\circ}$ do Estatuto da Corte:

A Corte Permanente de Justiça Internacional é um corpo de magistrados independentes, eleitos, desconsiderando sua nacionalidade, de entre pessoas que gozem de alta consideração moral e possuam as condições exigidas nos seus respectivos países para o desempenho das mais altas funções judiciais, ou que sejam jurisconsultos de reconhecida competência em direito internacional ${ }^{45}$.

Além da positivação da necessidade de alta qualificação para indicação à Corte, o dispositivo aporta outro elemento importante para o debate acerca da figura do juiz da Corte Permanente. Tal artigo estabelece o dever de se negligenciar a nacionalidade no momento da eleição dos juízes. Tal hipótese não parece se verificar com perfeição porquanto se percebe uma clara tendência à nacionalização dos juízes na composição da Corte. Tal quadro se agudiza ao se considerar que, segundo Hudson, a questão da imparcialidade vem definida através da nacionalidade distinta dos juízes, diferentemente da composição arbitral ${ }^{46}$,

\footnotetext{
42 OPPENHEIM, 1919, p. 63. Do original: "men who are linguists, knowing, at anyrate, the French language besides their own; men who possess independence of character and are free from national prejudices of every kind"

${ }^{43}$ Artigo 21 do Estatuto da CPJI: "La Cour elit, pour trois ans, son President et son Vice-President ; ils sont reeligibles. Elle nomme son Greffier".

${ }^{44}$ POLITIS, 1924, p.163.

${ }^{45}$ Do original: La Cour Permanente de Justice Internationale est un corps de magistrats independants, elus, sans egard a leur nationalite, parmi les personnes jouissant de la plus haute consideration morale, et qui reunissent les conditions requises pour l'exercice, dans leurs pays respectifs, des plus hautes fonctions judiciaires, ou qui sont des jurisconsultes possedant une competence notoire en matiere de droit international.

${ }^{46}$ HUDSON, 1922, p. 257.
} 
O SURGIMENTO DA CORTE PERMANENTE DE JUSTIÇA INTERNACIONAL: FORMAÇÃO EUROPEIA E FUNDAMENTO VOLUNTARISTA

LUCAS CARLOS LIMA

Considerando a importância da nacionalidade na nomeação do juiz e a fim de extirpar a nova Corte de qualquer mácula, criou-se a hipótese do “juiz ad hoc” ou juiz nacional regulado pelo artigo $31^{47}$. Considerada uma das inovações da Corte, tal previsão estabelecia que, no caso das partes em litígio possuírem um juiz da mesma nacionalidade, a outra parte poderá indicar um juiz ad hoc para compor a Corte. Nas palavras de Charles Rousseau" ${ }^{48}$, "não basta que a justiça seja justa, é necessário que ela pareça justa”, motivo pelo qual se argumenta que a existência de um juiz de uma nacionalidade alteraria o equilíbrio da balança.

Duas breves exortações podem ser efetuadas no que se refere a essa instituição. A primeira delas é a hipótese desta disposição ser ou não uma eventual contradição ao princípio do juiz ser desvinculado à sua nacionalidade nos ditames do art. $2^{\circ}$ do Estatuto anteriormente referenciado. Afinal, se determinado juiz é escolhido em se desconsiderando sua nacionalidade, consectário lógico que, na hipótese aventada pelo Estatuto, não votará necessariamente a favor de seu país numa causa. A crítica que aqui se perfaz volta-se não contra o instituto do juiz ad hoc, instituto esse extremamente necessário à melhor aceitação da sentença pelos Estados, mas sim à tentativa do estatuto de extirpar hermeticamente o elemento da nacionalidade do juiz no artigo $2^{\circ}$ ao mesmo tempo em que o leva em consideração no art. 31 .

A segunda questão a ser sopesada é o caráter eminentemente arbitral que a escolha da Comissão encerra com a possibilidade de nomeação de um juiz ad hoc. Prática usual nas arbitragens internacionais (sobretudo nas comissões mistas), a paridade de partes e o princípio da equidade em que as partes nomeiam os árbitros para sua satisfação e para o aceite da decisão. Nesse sentido, Politis afirma que nesse momento a Corte se aproxima de uma espécie de tribunal arbitral ${ }^{49}$, vez que utiliza da antiga prática arbitral de inserir um juiz de cada nacionalidade para “equilibrar" o tribunal. Sobre a questão, Manley Hudson ${ }^{50}$ posiciona-se em igual sentido, afirmando ainda que tal instrumento fornece a base para afirmar que a nova Corte

\footnotetext{
${ }^{47}$ Art. 31 do Estatuto da CPJI: Les juges de la nationalite de chacune des parties en cause conservent le droit de sieger dans 1' affaire dont la Cour est saisie. Si la Cour compte sur le siege un juge de la nationalite d'une seule des parties, l'autre partie pent designer pour sieger un juge suppleant s'il s'en trouve un de sa nationalite. S'il n'en existe pas, elle pent choisir un juge, pris de preference parmi les personnes qui ont ete l'objet d'une presentation en conformite des articles 4 et 5 .

${ }^{48}$ ROUSSEAU, 1983, p. 403.

${ }^{49}$ POLITIS, 1924, p. 165.

${ }^{50}$ Manley Ottmer Hudson, (1886-1960), americano, juiz da Corte Permanente de Justiça Internacional e membro da Comissão de Direito Internacional das Nações Unidas. Foi nomeado duas vezes ao Prêmio Nobel da Paz. Sua obra The Permanent Court of International Justice 1920-1942, de 1943, é um verdadeiro compêndio sobre a atividade jurisdicional desta Corte.
} 
O SURGIMENTO DA CORTE PERMANENTE DE JUSTIÇA INTERNACIONAL: FORMAÇÃO EUROPEIA E FUNDAMENTO VOLUNTARISTA

LUCAS CARLOS LIMA

foi investida também de uma função “extrajudicial”, porquanto deixa suas bases permanentes e pré-definidas para remeter à parte a escolha do árbitro.

De todo modo, como anteriormente referenciado, a previsão é importante vez que com a possibilidade de reeleição estabelecida no Estatuto somada ao mandato de 9 anos ${ }^{51}$, tem-se a hipótese de um mesmo juiz de determinada nacionalidade permanecer por dezoito anos na Corte, porquanto não ser possível dois juízes de uma mesma nacionalidade comporem a Corte. Seus ordenados são pagos pela Liga das Nações, de maneira a desvincular completamente o juiz de qualquer atividade e também estimulando sua participação na Corte ${ }^{52}$.

Outra medida que foi adotada neste sentido pelo Comitê de juristas é a não obrigatoriedade de um juiz permanecer na Corte durante o ano inteiro. Em seu ensaio La Corte Permanente di Giustizia Internazionale, Gabriele Salvioli comenta que a obrigatoriedade de uma permanência ininterrupta desestimularia grandes personalidades do direito internacional a assumir seu posto ${ }^{53}$. O dever de constância na Corte durante todo o ano é do Presidente da Corte que também nomeará o Secretário (Registrar) da Corte, responsável pela documentação processual da Corte e pelo contato com os Governos.

No que diz respeito aos reflexos que a Corte manifesta sobre a concepção de direito internacional de sua época verifica-se também a discussão em relações a sujeitos do Direito Internacional. A Corte é uma jurisdição fechada a Estados, o que se denota bem no artigo 34 do Estatuto quando dispõe que "somente os Estados ou Membros da Liga das Nações podem ser partes perante a Corte" ${ }^{, 54}$. Ainda que houvesse a previsão para os casos em que não membros da Liga viessem compor a Corte ${ }^{55}$, a restrição estatal mantinha-se em vigor para evitar (e proteger) que os Estados fossem demandados por outras autoridades que não Estados. Para Politis, este é

\footnotetext{
${ }^{51}$ Artigo 13 do Estatuto da CPJI: "Les membres de la Cour sont elus pour neuf ans.lls sont reeligibles. Ils restent en fonction jusqu'i leur remplacement. Après ce remplacement, ils continuent de connaitre des affaires dont ils sont dejà saisis".

${ }^{52}$ Expresso em florins holandeses, o ordenado anual dos juízes encerra-se na cifra de 15 mil florins, aproximadamente $U \$ 6,030$ por ano. 0 Presidente da Corte recebe um adicional de 45 mil florins, sendo que todos os juízes possuem direito ao ressarcimento de despesas adicionais como moradia e viagens (MOORE, 1924, p.51). A quantia aproximada que ganha um juiz da Corte Internacional de Justiça hoje é de $\mathrm{R} \$ 32,5$ mil mensais.

${ }^{53}$ SALVIOLI, 1924, p.63.

${ }^{54}$ Do original: "Seuls les Etats ou les Membres de la Societe des Nations ont qualite pour se presenter devant la Cour."

${ }^{55}$ Art. 34 do Estatuto: "Les conditions auxqueUes elle est ouverte aux autres Etats sont, sous reserve des dispositions particulieres des traites en vigueur, reglees par le Conseil, et dans tous les cas, sans qu'il puisse en resulter pour les parties aucune inegalite devant la Cour. Lorsqu'un Etat, qui n'est pas Membre de la Societe des Nations, est partie en cause, la Cour fixera la contribution aux frais de la Cour, que cette partie devra supporter".
} 
O SURGIMENTO DA CORTE PERMANENTE DE JUSTIÇA INTERNACIONAL: FORMAÇÃO EUROPEIA E FUNDAMENTO VOLUNTARISTA

LUCAS CARLOS LIMA

outro "limite" 56 à Justiça internacional. O debate acerca do papel cada vez maior do indivíduo no Direito Internacional é profícuo no período, sobretudo no que se refere à Escola Francesa do Direito Internacional ${ }^{57}$.

0 posicionamento do indivíduo atende a dois desdobramentos importantes quando inserido no debate acerca da jurisdição internacional. O primeiro deles é a esperança de que uma Corte Internacional servisse como um verdadeiro tribunal acima dos Estados, como instância última a qual os indivíduos pudessem recorrer. Hoje tal concepção é bastante clara nos meios internacionais, sobretudo no que se refere às jurisdições de proteção aos Direitos Humanos, contudo, realizando-se um sopesamento histórico, pode-se perceber que a inovação que representou a CPJI também traz este tipo de questionamento. Isto porque de certa forma o debate não havia sido superado. A título de exemplo, sabe-se que a Corte Internacional de Presas proposta (mas não em vigor) no âmbito das Convenções de Haia de 1907 permitia que indivíduos a ela recorressem, bem como a Corte Centro-Americana de Justiça, a qual disciplinava a possibilidade de indivíduos acionarem diretamente Estados. Mesmo para Politis, seria prematuro conceder o acesso a Corte para que particulares agissem contra Estados ${ }^{58}$.

A segunda questão importante é que a CPJI mantém a formação arbitral de relações inter-Estatais, optando mais uma vez por servir aos interesses dos Estados-parte da Liga. Ou seja, na concepção arbitral que vigia na Corte Permanente de Arbitragem também era impedido a particulares demandarem contra Estados, e tal concepção subsistiu ao debate do papel do indivíduo.

Retomando as considerações acerca da competência da Corte Permanente de Justiça Internacional, importantes são as palavras de Ole Spiermann, ao qualificar a discussão e a formação da competência da Corte como um passo adiante rumo à adjudicação, um passo de volta à arbitragem ${ }^{59}$. Tal afirmação se verifica na medida em que os trabalhos do Comitê de Juristas sempre privilegiaram a ideia de formar uma Corte Internacional de jurisdição contenciosa compulsória ${ }^{60}$. Contudo, tal proposição não encontrou chancela na vontade política dos Estados da Liga, de maneira que sua obrigatoriedade naufragou.

\footnotetext{
${ }^{56}$ POLITIS, 1926, p.448.

${ }^{57}$ Sobre a temática ver KOSKENNIEMI, Martti. El discreto civilizador de Naciones: el auge y la caída del derecho internacional 1870-1960. Buenos Aires - Madrid: Ciudad Argentina. 2005, e POLITIS, Nicolas. Les Nouvelles Tendances Du Droit International. Libraire Hachette: Paris, 1927

${ }^{58}$ POLITIS, 1924, p. 166.

${ }^{59}$ SPIERMANN, 2005, p.10.

${ }^{60}$ Comitê de Juristas, Procès-verbaux, p.204-250.
} 
O SURGIMENTO DA CORTE PERMANENTE DE JUSTIÇA INTERNACIONAL: FORMAÇÃO EUROPEIA E FUNDAMENTO VOLUNTARISTA

LUCAS CARLOS LIMA

O discurso jurídico com o qual se escudou esta vontade política dos Estados foi o artigo 12 do Pacto da Liga das Nações, que dispunha a faculdade dos Estados de escolher qual método jurisdicional (arbitragem ou adjudicação) utilizaram na resolução dos seus conflitos ${ }^{61}$. Deste modo, a obrigatoriedade da resolução jurisdicional estaria ferindo o Pacto da Liga que prevê a liberdade de escolha. Contudo, tal argumentação jurídica não parece prosperar vez que uma vinculação obrigatória à solução jurisdicional não impediria efetivamente que os Estados escolhessem qual a metodologia para sua solução de conflitos. Verifica-se, pois, que os Estados ainda se encontravam demasiadamente apegados ao seu conceito de soberania e independência para efetivamente submeter-se a uma Corte longe de seu arbítrio.

Diante desse contexto, a Corte ainda que permanente, teria sua jurisdição contenciosa concatenada à ideia facultativa de jurisdição. Nesse sentido cabem as palavras Charles Rousseau, ao afirmar que "não há jurisdição na ordem internacional senão sobre a base da vontade do Estado, cujo consentimento é a condição prévia para a solução judicial”62. Sopesando a questão neste sentido, o juiz da corte John Moore em ensaio à Columbia Review em 1922 igualmente ponderou que a jurisdição da Corte, excetuando os casos em que fora disposto o contrário, é totalmente voluntária ${ }^{63}$.

Esta é outra característica da Corte que será analisada com maior precisão. Ainda hoje o fundamento voluntarista é bastante evidente nas jurisdições internacionais, seja na admissão de competência, seja na execução das sentenças proferidas, e esta característica não foi exceção no primeiro órgão jurisdicional permanente da Comunidade Internacional.

\section{AS RAÍZES VOLUNTARISTAS DA PRIMEIRA JURISDIÇÃO INTERNACIONAL}

Cabe, ante a perspectiva que se abre com a questão do fundamento teórico que legitima o trabalho da Corte Permanente de Justiça Internacional, examinar a corrente doutrinal que fundamenta a ideia de vontade dos Estados como fundamento do direito. Nesse norte, dois são os grandes nomes que despontam na ciência jurídica como defensores de um

\footnotetext{
${ }^{61}$ Cf. BOURGEOIS, 1920, p.76.

${ }^{62}$ ROUSSEAU, 1966, p.351.

${ }^{63}$ MOORE, 1922 , p.511.
} 
O SURGIMENTO DA CORTE PERMANENTE DE JUSTIÇA INTERNACIONAL: FORMAÇÃO EUROPEIA E FUNDAMENTO VOLUNTARISTA

LUCAS CARLOS LIMA

neovoluntarismo como fundamento do direito internacional: Henrich Triepel $^{64}$ e Dionísio Anzilotti ${ }^{65}$.

Em seu Corso di Diritto Internazionale, Anzilotti ${ }^{66}$ sustenta que direito internacional, ou seja, o ordenamento jurídico da comunidade dos Estados, é composto das normas que encontram no pacta sunt servanda ${ }^{67}$ o fundamento de sua existência. Faz referência que, ao contrário do direito interno, o princípio do pacta sunt servanda não repousa sobre uma norma superior; é ele a norma suprema ${ }^{68}$. Significa dizer que é no próprio compromisso, na declaração da vontade, que se encontra no âmbito internacional a força "coatora" que no direito interno a figura do Estado representa. Em que pese não existir no direito internacional tal figura hierarquicamente superior, não se pode declarar uma "anarquia" exatamente pelo fato de no pacta sunt servanda se fundamentar tal ordenamento, ou seja, na vontade dos Estados e no seu próprio compromisso de respeitar as normas das quais é criador.

O caráter voluntarista da obra de Anzilotti é inegável e sobre seu prisma podemos analisar sua concepção de resolução pacífica de controvérsias, ou melhor, do direito que regula a solução destas controvérsias. É faculdade dos Estados escolher o meio pelo qual resolverá suas controvérsias e não existe, a priori, limitação para esta predileção. Tal concepção do jurista

\footnotetext{
${ }^{64}$ Heinrich Triepel (1868-1946), é um jurista germânico e professor de direito internacional em Berlim. Além de ser considerado um dos pais do neovoluntarismo, Triepel é considerado o fundador da doutrina dualista no direito internacional. Cf. TRUYOL, 1970, p.58.

${ }^{65}$ Nascido em 1867, na cidade de Pescia (região da Toscana, província de Pistoia), Anzilotti faleceu em 1950 na mesma cidade, para onde se retirou após sua aposentadoria. Dionisio Anzilotti, que desde o início de seus estudos e carreira tratou de diversos aspectos do Direito Internacional, tanto público como privado, é considerado um dos pais da escola italiana de Direito Internacional, tendo influência direta nos internacionalistas italianos do século XX. Em 1919 foi conselheiro jurídico e delegado técnico do governo italiano na Conferência de Paris. Em 1916 nomeado subsecretário geral da Liga das Nações, e em 1920 participou nos trabalhos preparatórios do Estatuto da Corte Permanente de Justiça Internacional. Em 1921 foi juiz da corte e presidente da mesma de 1928 a 1930. Em 1930 foi eleito para um segundo mandato de nove anos. Além disto, fundou a Rivista di Diritto Internazionale, uma das principais publicações especializadas, membro do Instituto de Direito Internacional, do Curatorium da Academia de Direito Internacional de Haia.

${ }_{66}^{60}$ ANZILOTTI, 1964, p.45.

${ }^{67}$ Numa tradução livre, "os pactos devem ser cumpridos". Em termos de direito internacional, o princípio significa dizer que os Estados devem respeitar os pactos firmados entre eles.

${ }^{68}$ ANZILOTI, 1964, p. 44-45. Do original: "Ogni ordenamento giuridico consta di un complesso di norme, che desumono il loro valore obbligatorio da uma norma fondamentale, allá quale tutte, direttamente o indirettamente, si riconducono. La norma fondamentale determina portanto quali sono le norme che compongono um dato ordinamento giuridico e lê raccoglie ad unità. Ciò che distingue l'ordinamento internazionale è che in esso il principio pacta sunt servanda non riposa come nel diritto interno, sopra uma norma superiore; è esso stesso la norma suprema. La regola secondo cui 'gli Stati devono rispetare $i$ patti conclusi fra loro' constituisce pertanto il criterio formale, che distingue le norme di cui parliamo dalle altre e lê raccoglie ad unità. (...) Queste norme constituiscono il diritto internazionale, cioè 'l'ordinamento giuridico della comunità degli Stati'",'
} 
O SURGIMENTO DA CORTE PERMANENTE DE JUSTIÇA INTERNACIONAL: FORMAÇÃO EUROPEIA E FUNDAMENTO VOLUNTARISTA

LUCAS CARLOS LIMA

italiano verifica-se numa das primeiras oportunidades que a CPJI encontrou para se pronunciar, no caso do parecer consultivo da Carélia Oriental de 1923, situação na qual se esclareceu que “está bem estabelecido no direito internacional que nenhum Estado será obrigado de submeter suas diferenças com outros Estados, seja à mediação, seja à arbitragem, seja enfim a qualquer processo de solução pacífica, sem seu consentimento" ${ }^{69}$.

Também sobre a vontade dos Estados Anzilotti coloca o fundamento da arbitragem internacional. São as vontades de dois ou mais Estados de dirimir determinada controvérsia que colocam a lide sobre o juízo de um terceiro que sobre o direito dará fim à controvérsia. Num momento histórico em que inexistiam tribunais internacionais, o autor italiano afirma ser a arbitragem o exercício da jurisdição, ou pelo menos uma substituição à função jurisdicional no âmbito internacional $^{70}$ e seu conceito se estende para o fundamento das jurisdições internacionais, como preleciona Gabriele Salvioli ${ }^{71}$.

O elemento eminentemente voluntarista que constitui a resolução pacífica de controvérsias e a dinâmica dos tribunais internacionais não se verifica tão somente na doutrina, como em seus próprios julgados iniciais a CPJI reafirma o caráter voluntarista de seu fundamento. A título de exemplo pode-se citar o Caso Mavrommatis, de 1924, entre Grécia e Reino Unido, no qual o preâmbulo dispõe que "a Corte, considerando o fato que sua jurisdição é limitada, que ela se funda sempre no consentimento da parte acusada"72.

Em verdade, ao longo de sua jurisprudência não faltam casos relembrando o caráter limitado da jurisdição da Corte. De maneira clara e decisiva, o acórdão de 1928 do Caso dos Fosfatos Marroquinos dispôs que "a jurisdição não existe senão nos termos nos quais ela foi aceita"73. Tal construção jurisprudencial endossando a concepção de que somente o consentimento dos Estados pode gerar obrigações internacionais verifica-se igualmente na jurisprudência da Corte Internacional de Justiça $(\mathrm{CIJ})$, considerada a sucessora da CPJI, ao

\footnotetext{
${ }^{69}$ Do original: “ll est bien établi en droit international qu'aucun État ne saurait être obligé de soumettre ses différends avec les autres États soit à la médiation, soit à l'arbitrage, soit enfin à n'importe quel procédé de solution pacifique, sans son consentement" (CPJI, Parecer Consultivo da Carélia Oriental, Série $B, n^{\circ} 5,1923$ p.27,)

70 “(...) si tratta di definizione di controversie mediante un giudizio altrui, figura logica che constituisce l'affinità piú spiccata e costante fra l'arbitrato e il processo, così è stato facile il passo a considerare l'arbitrato internazionale come esercizio di giurisdizione o, per lo meno, come un sostitutivo della funzione giurisdizionale." ANZILOTTI, 1915, p.42

${ }^{71}$ SALVIOLI, 1924, p.39.

${ }^{72}$ Do original: "La Cour, en considération du fait que sa jurisdiction est limitée, qu'elle se fonde toujours sur le consentement du défendeur..." (CPJI, Caso Mavrommatis, Série A, n² 2, 1924, p.16)

73 "La jurisdiction n'existe que dans les termes où elle a été acceptée" (CPJI, Caso dos Fosfatos Marroquinos, Série A, $n^{\circ} 28,1928$ )
} 
O SURGIMENTO DA CORTE PERMANENTE DE JUSTIÇA INTERNACIONAL: FORMAÇÃO EUROPEIA E FUNDAMENTO VOLUNTARISTA

LUCAS CARLOS LIMA

afirmar, em 1948, no parecer consultivo do Estreito de Corfu de 1948, que "o consentimento dos Estados parte a um litígio é o fundamento da jurisdição da Corte em matéria contenciosa”74.

Tal elemento voluntário é utilizado tanto para a Corte declarar-se competente como igualmente para declarar-se incompetente para julgar determinado litígio. No caso da Carélia Oriental, por exemplo, na opinião consultiva de 1923, a Corte se absteve de se pronunciar, mesmo na forma de questão consultiva, vez que a jurisdição da Corte só poderia ocorrer com base no consentimento, não podendo um Estado estar submetido à justiça internacional sem seu consentimento. De tal forma, como a URSS se negava a participar do procedimento, a Corte se absteve de se pronunciar, vez que estaria resolvendo a questão entre os Estados ${ }^{75}$, o que só permitido na seara contenciosa da Corte.

A jurisdição contenciosa da Corte Permanente estaria, portanto, estendida somente aos Estados que a ela voluntariamente se submetessem. Nesta perspectiva, três são as formas jurisdição contenciosa orquestradas pela Corte Permanente: a) a jurisdição facultativa; b) a jurisdição obrigatória por cláusula anterior; c) a cláusula facultativa de jurisdição obrigatória.

No que concerne à jurisdição facultativa (a), a regra geral, trata-se do litígio que surge entre Estados em que ambos decidem submeter a contenda à Corte e vem regulada pelo artigo 36 do Estatuto: “A competência da Corte estende-se a todos os litígios que as partes submetam à Corte, bem como a todos os casos especialmente previstos nos tratados e convenções em vigor"76. No mesmo artigo verifica-se também a jurisdição obrigatória da Corte (b) delineada na disposição de que em todos os tratados e convenções em que se encontrar estipulada a CPJI para resolver um litígio, o Estado não poderá dela se esquivar.

A novidade da Corte fez com que os tratados internacionais que anteriormente previssem a Corte Permanente de Arbitragem como metodologia para resolução de um litígio agora delimitassem que seria a CPJI a atuar. Nesse sentido, a partir de 1920, a CPJI começou a figurar nos tratados e pactos de uma maneira crescente ${ }^{77}$. Contudo, como anteriormente anunciado, tal jurisdição “obrigatória” não deixa de ser igualmente voluntária vez que exige uma anterior emissão de vontade do Estado para sua vinculação.

\footnotetext{
${ }^{74}$ Do original: "Le consentement des Etats parties à un differend est le fondement de la jurisdiction de la Cour en matière contentieuse" (CIJ, Parecer Consultivo do Caso Corfu, Recueil, p.16, 1948.). Em igual maneira: "O tribunal não pode exercer sua jurisdição a respeito de um Estado se não tiver 0 consentimento deste último" (CIJ, Caso do Ouro monetário verificado em Roma em 1943, 1954, p.32)

75 ROUSSEAU, 1983 , p. 360.

${ }^{76}$ Do original: "La competence de la Cour s'etend a toutes affaires que les parties lui soumettront, ainsi qu'a tous les cas specialement prevus dans les traites et conventions en vigueu".

${ }_{77}$ OPPENHEIM, 1921, P.38.
} 
O SURGIMENTO DA CORTE PERMANENTE DE JUSTIÇA INTERNACIONAL: FORMAÇÃO EUROPEIA E FUNDAMENTO VOLUNTARISTA

LUCAS CARLOS LIMA

Por fim, a grande inovação que a Corte trouxe em matéria de competência veio por sugestão do jurista brasileiro Raul Fernandes: a cláusula opcional de jurisdição obrigatória. Através de tal cláusula, segundo a redação do artigo 36 do Estatuto ${ }^{78}$, os Estados comprometiamse a aceitar uma jurisdição compulsória ipso factu, sem a necessidade de posterior ou anterior aceitação pactícia. Avizinhando-se consideravelmente da ideia de direito nacional, os Estados após o aceite de cláusula viam-se diretamente obrigados à triangulação processual, sem poder repelir as lides contra si intentadas com base na não-pactuação.

Cabe aqui acrescentar que referenciado dispositivo explicitava restritivamente as questões as quais estariam submetidas a esta jurisdição compulsória. Outra consideração importante que deve ser realizada é que a estipulação da cláusula obrigatória não exigia a reciprocidade para sua efetivação ${ }^{79}$, ou seja, um Estado que não estivesse vinculado à cláusula optativa de jurisdição obrigatória poderia, na medida de seus interesses, demandar um Estado que a ela estivesse vinculado sendo impossível a este recusar a jurisdição da Corte.

Interessante perceber que no ano de 1929 somente 28 Estados tinham se vinculado a esta cláusula, dentre os quais apenas a Alemanha figurava como grande potência ${ }^{80}$. Pode-se questionar, por exemplo, se tal quadro não revela que a jurisdição internacional arquitetada pelas grandes potências não servia para vincular as menores à jurisdição obrigatória sem, contudo, atrelar as grandes à essa obrigação judicial. Ainda que a ideia tenha surgido do representante de um Estado “menor”, ela bem servia à estrutura política das Grandes potências e talvez sem ela, a Corte jamais tivesse conhecido qualquer esquema de adjudicação compulsória.

Está-se até o momento tratando da jurisdição contenciosa da Corte por opor-se diametralmente àquela outra inovação da Corte que é a sua jurisdição consultiva, concretizada

\footnotetext{
${ }^{78}$ Artigo 36 do Estatuto da CPJI: (...)" Les Membres de la Societe et Etats mentionnes a l'Annexe au Facte pourront, soit lors de la signature ou de la ratification du Frotocole, auquel le present acte est joint, soit ulterieurement, declarer reconnaitre des a present comme obligatoire, de plein droit et sans convention speciale, visa-a-vis de tout autre Membre ou Etat accept ant la même obligation, la juridiction de la Cour sur toutes ou quelquesunesdes categories de differends d'ordre juridique ayant pour objet:

a) L'interpretation d'un Traite; b) Tout point de droit international; c) La realite de tout fait qui, s'il etait etabli, constituerait; la violation d'un engagement international.

d) La nature ou l'etendue de la reparation due pour la rupture d'un engagement international.

La declaration ci-dessus visee pourra 6 tre faite purement et simplement ou sous condition de reciprocite de la part de plusieurs ou de certains Membres ou Etats, ou pour un délai determine.

En cas de contestation sur le point de savoir si la Cour est competente, la Cour decide."

${ }^{79}$ Artigo 36 do Estatuto: “(...)La declaration ci-dessus visee pourra 6tre faite purement et simplement ou sous condition de reciprocite de la part de plusieurs ou de certains Membres ou Etats, ou pour un delai determin".

${ }^{80}$ ROUSSEAU, 1966, p.358.
} 
O SURGIMENTO DA CORTE PERMANENTE DE JUSTIÇA INTERNACIONAL: FORMAÇÃO EUROPEIA E FUNDAMENTO VOLUNTARISTA

LUCAS CARLOS LIMA

nos pareceres consultivos (avis consultatifs no francês, advisory opinions em inglês). Também esta se configura uma diferenciação da CPJI em relação à arbitragem internacional. Estabelecida pelo artigo 14 do Pacto da Liga das Nações como um segundo desdobramento da jurisdição da Corte $^{81}$, a função consultiva da CPJI restringe-se às solicitações realizadas pela Assembleia e pelo Conselho. A CPJI ganha o papel, pois, de órgão de assessoramento jurídico da organização internacional, desempenhando também esta função essencialmente restrita à organização.

Essa tese se verifica na primeira atividade jurisdicional da Corte após a sessão solene inaugurando os trabalhos em 15 de fevereiro de 1922. Em artigo publicado na Harvard Law Review, o juiz sueco Ake Hammarskjöld analisa os três primeiros pareceres consultivos proferidos pela Corte. Todos eles envolviam interpretação do Tratado de Versalhes a respeito da Alemanha, sobretudo em questões trabalhistas ${ }^{82}$. Nesse primeiro momento a Corte já demonstrara seu caráter de assessor jurídico do Conselho que se via diante de situações práticas a gerir diante das obrigações impostas pelo Tratado de Versalhes, mas havia discussões acerca da aplicação destas normas ${ }^{83}$.

É exatamente este caráter de assessoramento jurídico que será reprovado por autores como Nicolas Politis e Marshall Brown, que tecerão duras críticas à função consultiva da Corte, afirmando não ser ela um verdadeiro exercício da função jurisdicional ${ }^{84}$. Independente de tal fato, a função consultiva da Corte demonstrou-se (e ainda demonstra-se, ao se pensar na frutífera atividade da Corte Internacional de Justiça nesse sentido) inteiramente plástica à necessidade de uma organização internacional solucionando-lhe problemas num debate entre os principais juristas indicados daquela instituição.

De todo modo, o panorama da competência da Corte em suas três frentes (facultativa e obrigatória em dois vieses) é complementado por outra inovação da CPJI em relação à

${ }^{81}$ Ole Spiermann trata o tema pelo termo "a dupla jurisdição do artigo 14 do Pacto" (SPIERMANN, 2005, p.13)

82 Hammarskjöld, 1923, p.717. Nesse sentido: Thus the first of the questions was " whether the Dutch Workers' Delegate at the Third International Labor Conference had been nominated in accordance with the provisions of paragraph 3 of art. 389 of the Treaty of Versailles," whilst the second question was " whether the competence of the International Labor Organization extends to the international regulation of the conditions of labor of persons employed in agriculture," and the third, " whether examination of proposals for the organization and development of the methods of agricultural production and of other questions of a like character fall within the competence of the International Labor Organization." (HAMMARSKJOLD, 1923, P.17)

${ }^{83}$ Hammarskjöld, 1923, p.722.

${ }^{84}$ ROUSSEAU, 1983, p.416. 
O SURGIMENTO DA CORTE PERMANENTE DE JUSTIÇA INTERNACIONAL: FORMAÇÃO EUROPEIA E FUNDAMENTO VOLUNTARISTA

LUCAS CARLOS LIMA

arbitragem internacional: a capacidade de declarar sua própria competência ${ }^{85}$. Assim, ainda que um Estado no início de uma lide levante argumentação preliminar de que não se encontra plenamente vinculado ao corpo jurisdicional, será a Corte a decidir se este argumento procede ou não, se ela possui competência para julgar a lide ou não.

Os argumentos acima colacionados demonstram a existência de certa tensão na atividade de construção da Corte (na forja de seu Estatuto) e a imagem de jurisdição internacional permanente idealizada pelos seus defensores doutrinais ${ }^{86}$. Mesmo em 1931, em curso oferecido na Academia de Direito Internacional de Haia sobre a Corte, Mégalos Caloyanni ${ }^{87}$ afirmava que as necessidades do pós-guerra reclamaram uma nova organização de Justiça internacional, o direito internacional progredido de diversas formas, o fixou. De outro lado, a atrocidade humana reclama as organizações especiais e especializadas, tudo converge para uma organização uniforme, completa, de Justiça Internacional ${ }^{88}$. A visão idealizada e ligeiramente descompassada com a realidade de Caloyanni chega a firmar que "a ideia absoluta da Soberania perde já bastante de sua intransigência" ${ }^{89}$.

A hipótese de Caloyanni não parece se verificar vez que a intransigência da soberania é que baliza a capacidade de jurisdição da Corte, bem como submeteu sua já enfraquecida fórmula de jurisdição compulsória a um rol taxativo (embora amplo) do artigo 36 do Estatuto da Corte.

Exigindo seu tributo, a Soberania dos Estados também só vai permitir a existência de uma Corte Permanente se identificar precisamente qual será o direito a ser aplicado por aquele tribunal. Se no procedimento arbitral era claro que as partes é que escolheriam quais normas compunham a lide, num procedimento judiciário esta prerrogativa não era translúcida. $\mathrm{Na}$ sistematização das fontes e na indicação, o Comitê de Juristas elaborou um dos artigos mais importantes para a dinâmica das fontes do Direito Internacional, o artigo 38:

\footnotetext{
${ }^{85}$ Segundo Politis: "Today, while contestants before the Court are free to challenge its competence, as before any other tribunal, it remains for the Court itself to rule on the point whether or not it is competent to act" (POLITIS, 1926, p.950).

${ }^{86}$ Como apontou Wehberg, 1918.

${ }^{87}$ Mégalos A. Caloyanni (1869-) é um internacionalista grego. Membro do International Law Association, é um dos principais nome da ciência jurídica helênica ao lado de Nicolas Politis. Entre suas principais publicações está um ensaio de 1926 sobre a Corte Permanente de Justiça Internacional e seu curso lecionado na academia de direito internacional de Haia.

${ }^{88}$ CALOYANNI, 1931, p.775.

${ }^{89}$ CALOYANNI, 1931, p.777. Do original: "lidée absolue de la Souveraineté perd éja beaucoup de son intransigeance".
} 


\section{ISSN 1981-3694

O SURGIMENTO DA CORTE PERMANENTE DE JUSTIÇA INTERNACIONAL: FORMAÇÃO EUROPEIA E FUNDAMENTO VOLUNTARISTA

LUCAS CARLOS LIMA

\section{A Corte aplicará:}

1. As convenções internacionais, quer gerais, quer especiais, que estabeleçam regras expressamente reconhecidas pelos Estados litigantes;

2. O costume internacional, como prova de uma prática geral aceite como direito;

3. Os princípios gerais de direito, reconhecidos pelas nações civilizadas;

4. Com ressalva das disposições do artigo 59 , as decisões judiciais e a doutrina dos publicistas mais qualificados das diferentes nações, como meio auxiliar para a determinação das regras de direito.

5. A presente disposição não prejudicará a faculdade da Corte de decidir uma questão ex aequo et bono, se as partes assim convierem ${ }^{90}$.

Mantendo-se basicamente intacto no Estatuto da atual Corte Internacional de Justiça, o presente dispositivo é referência obrigatória nos manuais de Direito Internacional ao se tratar das fontes do direito da comunidade dos Estados. Os três primeiros pontos do artigo não necessitam de maiores digressões. Contudo, o quarto e o quinto merecem as necessárias ponderações.

O dispositivo que prevê que as "decisões judiciais" serão aplicadas como "meio auxiliar" para a determinação do direito é a referência da própria Corte informando a aplicação de sua jurisprudência como fonte. No âmbito das discussões do Comitê de Juristas havia a proposta de não inserir estes termos vez que estariam insertos na indicação do costume como fonte. Assim, foi necessário inserir o termo "como meio auxiliar". Ou seja, constituem somente um "elemento de interpretação" das normas verdadeiramente positivas. Contudo, o dispositivo mostra-se importante na medida em que permite ao Tribunal utilizar sua própria jurisprudência como precedente hermenêutico.

No que tange à disposição do estatuto de utilizar a equidade (ex aequo et bono) como fonte, Politis ${ }^{91}$ aponta que nesse sentido a Corte se aproxima também da prática assentada da arbitragem internacional vez que cabia aos árbitros por vezes utilizar mais a conciliação para pôr fim a um litígio que verdadeiramente decidir sobre razões jurídicas. Mas a aproximação é necessária, segundo o jurista francês. Isto porque esta inclusão no Estatuto seria para evitar que, na ausência de normas ou princípios que resolvessem determinado caso, e a Corte tivesse

\footnotetext{
${ }^{90}$ Do original: “La Cour appliqué: 1. Les conventions Internationales, soit generales, soit speciales, etablissant des regies expressement reconnues par les Etats en litige ; 2. La coutume Internationale comme preuve d'une pratique generale acceptee comme etant le droit; 3. Les principes generaux de droit reconnus par les nations civilisees ; 4. Sous reserve de la disposition de 1' article 59, les decisions judiciaires et la doctrine des publicistes les plus qualifies, comme moyen auxiliaire de determination des regles de droit. La presente disposition ne porte pas atteinte à la faculté pour la Cour, si les parties sont $d^{\prime}$ accord, de statuer ex aequo et bono".
}

${ }^{91}$ POLITIS, 1924, p. 170. 
de declinar de sua jurisdição, por isso a determinação de só admitir tal hipótese "se as partes assim convierem".

\section{CONCLUSÃO}

Evidenciada as principais características da Corte Permanente de Justiça Internacional, impende anotar que o itinerário até aqui realizado tinha como objetivo solevar as cardinais inovações e idiossincrasias da primeira jurisdição internacional permanente. A tensão entre soberania e jurisdição permanente, contudo, demonstra-se desde o primeiro momento marcar sua posição relembrando que os Estados vivem numa dinâmica que prescinde das lógicas do direito nacional.

Há que se considerar, igualmente, que a Corte trabalha sobre um profícuo processo de codificação do direito internacional realizado pela Liga das Nações. A função da Corte, dessa forma, vem complementar a própria criação "legiferante" da Liga das Nações.

Ainda que não estivesse vinculada à Liga das Nações diretamente (como é a CIJ com a ONU hoje, por exemplo) a dependência e co-relação entre as organizações era direta e orgânica. Não estranha portanto a consideração do professor Philip Allott em considerar a Corte como uma “das muitas tentativas de pseudo-constitucionalismo"92 no Direito Internacional.

A ideia de "pseudo-constitucionalismo" parece prosperar se averiguado o discurso imediatamente anterior à criação da Corte e a maneira idealizada que por todo seu percurso vem ornada com discursos festivos. Não estranha que autores afirmassem ser ela o "progresso da legalidade internacional". Contudo, uma legalidade diretamente atrelada à soberania e às limitações das vontades dos Estados. Seu estatuto provou-se ser uma construção erigida sob os auspícios de uma época e de uma determinada concepção de Estado, de relações internacionais e de jusinternacionalismo. Sua jurisprudência não singrou por vereda tão diversa.

Contudo, a experiência jurisdicional permanente também foi enxergada no interior do contexto político em que inserida. Distanciando-se de um ideal hermético de justiça, a criação de um tribunal internacional vinculado a uma organização internacional serviu no intento de manutenção do status quo arquitetado no Tratado de Versalhes, ao menos enquanto a estrutura política se conservava propícia à manutenção deste status quo. A Corte é um órgão

${ }^{92}$ ALLOTT, 2002, p.250. 


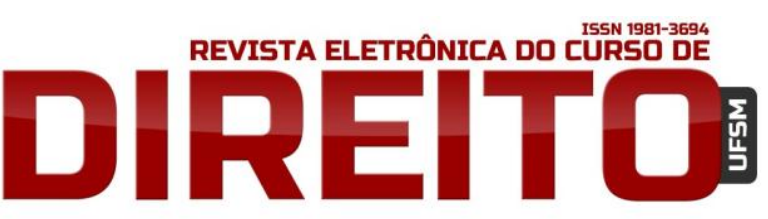

O SURGIMENTO DA CORTE PERMANENTE DE JUSTIÇA INTERNACIONAL: FORMAÇÃO EUROPEIA E FUNDAMENTO VOLUNTARISTA

LUCAS CARLOS LIMA

essencialmente europeu desde suas origens, quando se bosquejava sua estrutura por uma comissão de juristas cuja maioria pertencia à Europa. Sua composição também não diferiu nesse sentido, respeitando-se a força dos juristas oriundos das Grandes Potências, bem como representantes do velho continente.

O modelo jurisdicional de solução pacífica de controvérsias após a Corte Permanente é caracteristicamente distinto do modelo arbitral que a antecedeu. Alguns elementos comuns permanecem regendo suas dinâmicas e norteando sua atividade (como é o exemplo do voluntarismo), mas ainda que aproximações, rupturas e continuidades existam, a Corte Permanente de Justiça Internacional permanecerá sendo o divisor de água nesta perspectiva histórica.

\section{REFERÊNCIAS}

ALLOTT, Philip. The Health of Nations: Society and Law Beyond the State. London: Cambridge University Press, 2002.

ANZILOTTI, Dionísio. Corso di Diritto Internazionale. Volume Primo. $3^{\text {a }}$.ed. Padova: Cedam 1964.

ANZILOTTI, Dionísio. Corso di Diritto Internazionale. Volume Terzo: I Modi di Risoluzione delle Controversie Internazionali. Roma: Atheneum Società Editrice Romana, 1915.

BOURGEOIS, León. WEISS, André. The Permanent Court of International Justice. The League of Nations Starts, pp.59-81. London: Macmillan and Co, 1920

BROWNLIE, Ian. Principles of Public International Law. 5.ed. Oxford: Oxford University Press, 1998.

CALOYANNI, Mégalos A. L'Organisation de la Cour Permanente de Justice et son avenir. Recueil des Cours de l'Académie de Droit International, 1931.

CARR, Edward. Vinte Anos de Crise. 1919-1939. Brasília: Universidade de Brasília, 2001.

CORTE PERMANENTE DE JUSTIÇA INTERNACIONAL

CPJI, Caso dos Fosfatos Marroquinos, Série A, $\mathrm{n}^{\circ} 28,1928$

CPJI, Caso Mavrommatis, Série A, $n^{\circ} 2,1924$

CPJI, Free City of Danzig and ILO. Series B, Nº. 18, 1930.

CPJI, Parecer Consultivo da Carélia Oriental, Série B, n 5, 1923

CPJI: Free Zones Case, Série A/B 46, 1930. 


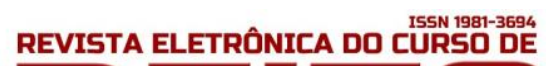

O SURGIMENTO DA CORTE PERMANENTE DE JUSTIÇA INTERNACIONAL: FORMAÇÃO EUROPEIA E FUNDAMENTO VOLUNTARISTA

LUCAS CARLOS LIMA

CPJI: Lotus Case, Série A 10, 1927.

CPJI: Wimbledon Case, Série A, I, 1923.

HAMMARSKJÖLD, Ake. The early work of the permanent court of international justice. Harvard Law Review, n. 36, 1922-3.

HUDSON, Manley O. The Permanent Court of International Justice 1920-1942. New York: The Macmillan Company, 1943.

HUDSON, Manley O. The Permanent Court of International Justice. Harvard Law Review, Vol. 35, N. 3, pp. 245-275, Jan. 1922.

HUDSON, Manley Ottmer. The Revision Of The Statute Of The World Court. Foreign Affairs, Vol. 9, no. 2 pp. 341-345, Janeiro, 1931.

KOSKENNIEMI, Martti. El discreto civilizador de Naciones: el auge y la caída del derecho internacional 1870-1960. Buenos Aires - Madrid: Ciudad Argentina. 2005. Trad. Natalia Zaragoza.

LAWRENCE, T. J. Les Principes de Droit International. Oxford: Imprimerie de L'Université, 1920.

LIMA, L. C. ; DAL RI JUNIOR, A . O desenvolvimento da arbitragem internacional ao longo do século XIX como movimento precursor das convenções da paz de haia de 1899 e 1907. In: $9^{\circ}$ Congresso Brasileiro de Direito Internacional, 2011, Brasília. Anais do $9^{\circ}$ Congresso Brasileiro de Direito Internacional, 2011. v. 1. p. 734-742.

MCWHINNEY, Edward. Judicial Settlement of International Disputes: Jurisdiction, Justiciability and Judicial Law-Making on the Contemporary International Court. London: Martinus Nijhoff Publishers, 1991.

MOORE, John Robert Basset. The Organization of the Permanent Court of International Justice. Columbia Law Review, Vol. 22, No 6, pp. 497-526, Junho de 1922.

OPPENHEIM, Lassa. The League of Nations and Its Problems. London: Longmans, Green and Co, 1919.

OPPENHEIM. Lassa. The Future of International Law. Oxford: Clarendon Press, 1921.

POLITIS, Nicolas. How the World Court has Functioned. Foreign Affairs, Vol. 4, n3. pp.443-453. Abril, 1926

POLITIS, Nicolas. La Justice Internationale. Paris: Librairie Hachette, 1924.

PROCÈS-VERBAUX of the Advisory Committee of Jurists on the Statute of the Permanent Court of International Justice, 1920. Disponível em: <http://www.icj-cij.org/pcij/other-

documents.php?p1=9\&p2=8>. Acesso em: 11 nov. 2011.

PROCĖS-VERBAUX of the Committee of Jurists on the Statute of the Permanent Court of International Justice, Minutes, 1929. Disponível em: <http://www.icj-cij.org/pcij/otherdocuments.php?p1=9\&p2=8>. Acesso em: 11 nov. 2011. 


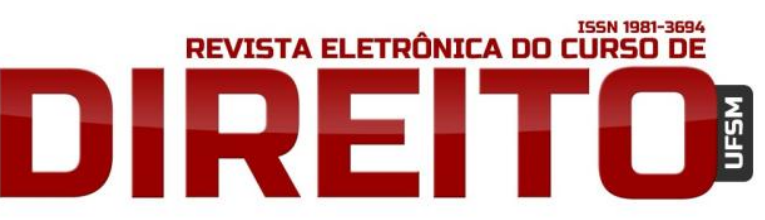

O SURGIMENTO DA CORTE PERMANENTE DE JUSTIÇA INTERNACIONAL: FORMAÇÃO EUROPEIA E FUNDAMENTO VOLUNTARISTA

LUCAS CARLOS LIMA

RANGEL. Vicente Marotta. Evolução da Justiça Internacional. MEDEIROS, Antônio Paulo Cachapuz (org). Desafios do Direito Internacional Contemporâneo: Jornadas de Direito Internacional Público no Itamaraty. Brasília: Fundação Alexandre de Gusmão, 2007.

ROOT, Elihu. The Constitution of an International Court of Justice. The American Journal of International Law, Vol. 15, No, 1. pp.1-12, Jan. de 1921.

ROOT, Elihu. The 'Great War' and the International Law. Washington, American Peace Society, 1921.

ROSSEAU, Charles. Droit International Public. Tome V. Les Rapports conflictuels. Paris: Sirey, 1983.

ROUSSEAU, Charles. Derecho Internacional Publico Profundizado. Buenos Aires: La Ley Editora, 1966.

SALVIOLI, Gabriele. La Corte Permanent di Giustizia Internazionale. Roma: Athenaeum, 1924

SALVIOLI, Gabriele. La Jurisprudence de la Cour permanente de Justice internationale. Recueil des Cours de l'Académie de Droit International, 1926.

SCELLE, Georges. Le Pacte des Nations et sa liaison avec Le Traité de Paix. Paris: Recueil Sirey, 1919.

SCOTT, James Brown. The Hague Peace Conferences of 1899 and 1907. Vol. 1. Baltimore: The Johns Hopkins Press, 1909.

SCOTT, James Brown. Une Cour de Justice Internationale. New York: Oxford University Press, 1918.

SEITENFUS, Ricardo. Manual das Organizações Internacionais. Porto Alegre: Livraria do Advogado Editora, 1997.

SPIERMANN, Ole. International Legal Argument in the Permanent Court of Internacional Justice. New York: Cambridge University Press, 2005.

TRUYOL, Antonio. Fundamentos de derecho internacional publico. Madrid: Editorial Tecnos, 1970.

VELAZCO, Manuel Diez de. Las Organizaciones Internacionales. Madrid: Editora Tecnos, 2006.

WEHBERG, Hans. The Problem of an International Court of Justice. Oxford: Clarendon Press, 1918.

Recebido em: 22 abr. 2013

Revisões requeridas: 24 jun. 2013

Aprovado em: 5 jul. 2013 